\title{
DO WOMEN BEHAVE FINANCIALLY WORSE THAN MEN? EVIDENCE FROM MARRIED AND COHABITING COUPLES
}

\section{Cwynar, A.}

Andrzej Cwynar / University of Economics and Innovation, Institute of Public Administration and Business, Projektowa 4, 20-209 Lublin, Poland. E-mail: andrzej.cwynar@wsei.lublin.pl

\begin{abstract}
Extensive empirical evidence shows that women perform worse in financial literacy tests, which implies that their financial behaviour may also be worse compared to men. However, the literature on the gender gap in financial behaviour is scanty and highly inconclusive. Using data from a survey of married and cohabiting couples living in Poland $(\mathrm{N}=1,000)$ and a multi-dimensional scale validated in terms of its psychometric properties, this article compares the financial behaviour of women and men. The applied tests did not show any significant gender differences in the overall financial behaviour index or in any of the subdomains of the behaviour distinguished in the applied scale. Using the social identity theory as a framework, we discuss possible explanations of these puzzling findings, which may imply that women are unnecessarily considered a disadvantaged group in terms of preparedness to participate in financial life, including the business sphere.

Implications for Central European audience: Assuming that the gender differences in financial literacy and behaviour can be explained on the grounds of the social identity theory, Central and Eastern Europe may differ from Western Europe in terms of the gender gap. Socially-imposed gender roles were presumably shaped differently behind the Iron Curtain, which resulted in that the distinction between masculine and feminine roles got blurred under the Soviet regime. As a result, the absence of gender differences in financial behaviour is more likely to occur in Central and Eastern European countries. Financial education initiatives should take this circumstance into account.
\end{abstract}

Keywords: financial behaviour; gender gap; financial literacy; social norms; social identity JEL Classification: D12, J16

\section{Introduction}

It is well documented that women perform worse in financial literacy tests (Bucher-Koenen, Lusardi, Alessie, \& van Rooij, 2017; Cupák, Fessler, Schneebaum, \& Silgoner, 2018; Hasler \& Lusardi, 2017; Hung, Yoong, \& Brown, 2012; Lusardi \& Mitchell, 2008; Moon, Ohk, \& Choi, 2014; OECD, 2016, 2020). Much less is known about gender differences in financial behaviour. Research on the subject is scarce, scattered and uses only partial measures of behaviour. Based on rich empirical evidence showing a strong positive correlation between financial literacy and desirable financial behaviour (see Stolper and 
Walter 2017 for an overview and discussion), one would expect that men should act more prudently in the financial domain. Such expectation is additionally supported by research findings showing that males are more often assigned the role of the household financial manager (Babiarz, Robb, \& Woodyard, 2012; Bernasek \& Bajtelsmit, 2002; Smith, McArdle, \& Willis, 2010), which gives them the opportunity to learn from experience and motivates them to invest in financial preparedness (Białowolski, Cwynar, \& Węziak-Białowolska, 2020; Mattia, Huston, \& Finke, 2017; Ward \& Lynch, 2019). However, previous research has brought mixed results regarding gender differences in financial behaviour. Large-scale OECD studies (OECD, 2016, 2020) identified relatively few differences between women and men in this respect. Even risk aversion research, which has a particularly long tradition, has not clearly confirmed differences between women and men in this regard (see a review provided by Barasinska and Schäfer 2018).

The aim of this article is to examine the financial behaviour of women and men using dyadic data and a validated in-depth scale consisting of four subdomains to measure it. The contribution of this study arises from the use of a comprehensive, multi-dimensional and fully validated instrument proposed by Dew and Xiao (2011) to gauge financial behaviour: the Financial Management Behaviour Scale (FMBS). This instrument not only allows for a measurement of financial behaviour in general but also, thanks to tested subscales, gives the opportunity to appraise this behaviour in four distinguished subdomains of household financial management.

A better understanding of gender differences in financial behaviour may have implications for designing financial education programmes. It is now accepted that women are a particularly vulnerable group that requires special support when it comes to developing financial competence. This belief is based on the results of studies that have observed a gender gap in financial literacy. However, the aim of raising financial literacy is to support desirable financial behaviour. If women do not exhibit worse financial behaviour than men, there is no reason to treat them as a disadvantaged group that requires special support. This does not change the fact that education addressed to them should, perhaps, be of a different nature than that addressed to men.

The findings of this article may also have business implications. On the one hand, they can help to verify the claim that women are underrepresented in the financial profession due to being inherently less financially savvy compared to men. The findings can also shed additional light on the well-established gender gap in entrepreneurship. On the other hand, they may also be a starting point for research aimed at better understanding why women are treated differently from men by some financial institutions. As a result, the initiatives targeted at a reduction of gender discrimination in business may be improved.

The article is structured as follows: the next section provides a literature review and lays the ground for hypotheses development. This is followed by the methodological part, in which we provide details regarding the survey and applied instruments. In the remaining sections, we discuss the results of the study and indicate its implications, limitations and directions for future research. 


\section{Literature review and hypotheses development}

\subsection{Theoretical background}

The literature on both the gender gap in financial literacy and the gender gap in financial behaviour rarely refers to theoretical models. However, in work on gender differences in financial literacy, several hypotheses have been put forward that could explain why women perform worse in financial literacy tests, including lesser interest of women in financial matters (Brown \& Graf, 2013), household labour specialisation (Hsu, 2016), the labour market hypothesis (Preston \& Wright, 2019), gender-related childhood socialisation (S. Agnew, Maras, \& Moon, 2018), the linguistic hypothesis (Boggio, Fornero, Prast, \& Sanders, 2015) and the gender gap in numeracy (Driva, Lührmann, \& Winter, 2016). We believe that these hypotheses have common underpinnings: all of them refer to social norms and the resulting cultural conditions. For this reason, we believe that the most appropriate theoretical framework to analyse the gender gap in financial literacy and behaviour is the theory of social identity formulated by social psychologists (Tajfel \& Turner, 1979). Akerlof and Kranton (2000) analyse the consequences of this theory for economic behaviour. The theory indicates that all individuals are assigned one of two abstract social categories - either "man" or "woman". These categories involve some behavioural prescriptions and socially desirable gender roles. Violation of these prescriptions may be costly for or detrimental to the individual who deviates from the social norm as it entails adverse consequences (anxiety, discomfort, conflicts, a decline in well-being). Hence, in order not to compromise payoffs resulting from conformity with social identity, individuals strive to follow the behavioural prescriptions for their gender.

From this identity (or culture-related) perspective, gender differences in financial literacy and behaviour arise as a result of social norms and stereotypes which are enforced by these norms. From early childhood, women and men throughout the world are nurtured to adopt socially desirable gender roles, learning that tasks related to the provision of security and means of subsistence - i.e. tasks manifesting themselves through household financial management - are mostly masculine. To adhere to social norms, women may refrain from involvement in financial activities, may delegate financial responsibility to their partners, may not invest in the acquisition of financial knowledge and skills and - as a result - may not have the motivation to maintain interest in financial matters or use financial language as predicted by the wide range of hypotheses mentioned above. Consequently, it is likely that they may end up with worse financial preparedness in terms of financial literacy and behaviour compared to men. Several recent studies brought empirical results supporting predictions of the social identity theory with regard to financial competences (Driva et al., 2016; Filipiak \& Walle, 2015).

Although financial behaviour research is the domain of microeconomics, the findings in this field may be essential for a better understanding of many gender-related phenomena observable in the business sphere. There is growing research that reveals the gender gap in entrepreneurship (Caliendo, Fossen, Kritikos, \& Wetter, 2015; Guzman \& Kacperczyk, 2019; Markussen \& Røed, 2017). A potential explanation of these findings can be unequal access of genders to financial markets. Van Staveren (2001) indicates that on the supply side of the financial market, the institutions can be more reluctant to provide women with financial services due to higher incomes and wealth levels reported by men. In fact, some 
studies found a form of discrimination of women in the access to financial services, which hinders entrepreneurial initiatives (Calcagnini, Giombini, \& Lenti, 2015; X. Chen, Huang, \& Ye, 2019; de Andrés, Gimeno, \& de Cabo, 2019). Kanze et al. (2018) showed that the entrepreneurial gender gap might result from asking male entrepreneurs promotion-focused questions and female entrepreneurs prevention-focused questions and that both genders respond to these questions in line with the theory of regulatory focus. These findings may suggest that the gender gap reflects a bias resulting from social norms rather than an objective and inherent lack of economic competences on the part of women. One cannot rule out the possibility that the bias is also responsible for the well-known gender gap in the financial profession (Getmansky Sherman \& Tookes, 2020), including the composition of the corporate executives (Catsalyst, 2020).

\subsection{Empirical findings on the gender gap in financial behaviour}

Financial behaviour is inherently risky, particularly when it comes to intertemporal behaviour related to investment and credit. Considering that research devoted strictly to gender differences in financial behaviour is scanty, some light on this issue may be shed by studies on risk aversion. As indicated by Barasinska and Schäfer (2018), risk aversion is the most frequently investigated issue in the research strand that focuses on the financial choices of women and men. Many studies showed that women report being less risk-taking than their male peers or that they behave in a more risk-averse way (Baeckstrom, Marsh, \& Silvester, 2019; Beckmann \& Menkhoff, 2008; Charness \& Gneezy, 2012; Powell \& Ansic, 1997; Weber, Weber, \& Nosić, 2013). Other researchers did not find differences between women and men in risk-taking preferences (Atkinson, Baird, \& Frye, 2003; Johnson \& Powell, 1994) or found a greater propensity to risk among women (Adams \& Ragunathan, 2017; Berger, Kick, \& Schaeck, 2014).

Some studies suggest that the presence or absence of the gender gap in risk aversion may result from the framing of behavioural experiments (for instance, a potential outcome can be framed as a loss or as a gain) (Schubert, Brown, Gysler, \& Brachinger, 1999). Others, however, reveal that women are more risk-averse regardless of the framing (Powell \& Ansic, 1997). Säve-Söderbergh (2012) established that the gender gap in risk choices, as reflected in portfolio composition, depends on which tails of the risk distribution are taken into account. No differences between genders were noticed among individuals choosing less risky portfolios, while men turned out to be significantly more risk-taking among those who held more risky portfolios. Dohmen et al. (2011) found out that the inclination to take risk varies across the life cycle differently for women and men, with men experiencing a continuous decline in the inclination and women experiencing a period of stability between the age of thirty and mid-fifties (the period is preceded and followed by a decrease in the inclination to take a risk). This finding coincides with the results of a meta-analysis of 150 studies in which gender differences in risk-taking were examined (Byrnes, Miller, \& Schafer, 1999): although men tend to be more risk-taking, the gender gap in this respect seems to shrink over time.

A growing number of experimental studies imply, however, that possible gender differences in risk aversion may reflect social context rather than intrinsic gender features. Gneezy, Leonard, and List (2009) compared women's inclination to compete in two types of societies - patriarchal (Maasai in Tanzania) and matrilineal (Khasi in India). According to 
their findings, men are more willing to compete in a patriarchal society, while women are more willing to compete in a matrilineal society. Booth and Nolen (2012), in turn, observed that the gender gap in the propensity to take risk depends on the gender composition of the experimental group. They reported that girls from single-sex schools were as likely to take a risk as boys and more likely than girls from co-ed schools. Additionally, girls assigned to allgirl experimental groups turned out to be more likely to take more risk. Similarly, Lindquist and Säve-Söderbergh (2011) established that women switched to more conservative competitive tactics when playing against men only, although they were more risk-taking when assigned to mixed or women-only groups. Black et al. (2017) found out that the investment behaviour of children is correlated with the investment behaviour of their parents, suggesting the presence of strong environmental determinants of financial behaviour.

Barasinska and Schäfer (2018) studied the link between gender and stock market participation in four European countries, different in terms of social norms and gender prescriptions resulting from these norms. Their findings indicate that in Italy - the country with the highest asymmetry in gender role prescriptions out of the four in focus - investment decisions made by women tended to be more risk-averse compared to the levels of risk acceptance they reported. As a result, Italian women were more likely to refrain from stock market participation compared to women from three other countries under study. Barasinska and Schäfer (2018) explain this deviation by referring to the social norms that apply in particular states and social environments which function within them. Italy is a country where risk-taking behaviour is considered a masculine domain, and, as a result, society does not support risky behaviour on the part of women. Consequently, women react by withdrawing from those behaviours that are not backed socially, including risk-taking, even though their inherent risk tolerance is not necessarily lower than among their male peers. In the same vein, Ke (2018) found out that households in states with more traditional gender norms are less likely to participate in the stock market. Almenberg and Dreber (2015) report the existence of the gender gap in stock market participation even in a country that strongly supports gender equality, such as Sweden, while van Rooij, Lusardi, and Alessie (2011) - in the Netherlands.

It is likely that gender differences in risk-taking propensity are further transmitted to investment and borrowing behaviours. It is well-documented that women invest differently than men. In a classic work on this issue, Barber and Odean (2001) show that male investors trade much more but perform worse than female ones. Charness and Gneezy (2012) found out that, on average, women invest less than men. There is also a strong body of evidence suggesting that investment portfolios held by women are less risky compared to portfolios composed by men (J. Agnew, Balduzzi, \& Sundén, 2003; Baeckstrom et al., 2019; Bajtelsmit, Bernasek, \& Jianakoplos, 1999; Huang \& De Luca, 2020). Gender differences were also found even in saving behaviour, which is inherently less risky (Fisher, 2010; Fisher, Hayhoe, \& Lown, 2015).

Johar and Rammohan (2011) found different patterns in the borrowing behaviour of women and men in Indonesia. They observed that although women were more likely to borrow informally from family members, this inclination did not decrease their interest in formal loans. Using data collected in Singapore, Agarwal et al. (2018) established that being involved in bankruptcy events is less likely among women by $28 \%$ compared to men and 
that this sizable gender difference can be mainly explained by risk-taking behaviour. Meyll and Pauls (2019), in turn, found out that over-indebtedness is less likely among women compared to their male peers and that this gender gap cannot be explained by risk attitude or financial literacy: they indicate the initial loan purpose as the factor at play here. Based on the data obtained from a Chinese peer-to-peer lending platform, X. Chen, Huang, and Ye (2019) report better borrowing outcomes on the part of women. Loans granted to female borrowers exhibited a lower probability of default, higher expected financial profit and lower expected financial loss compared to loans granted to men. Using a sample of selfemployed individuals, Nitani, Riding, and Orser (2020) show that, compared to men, women are less likely to use high-cost alternative financial services (AFS) such as payday loans, auto-title loans, rent-to-own transactions, pawnshops, cash-checking services, etc., even in spite of lower financial literacy. Some studies found that women and men also differ in behaviours that do not require intertemporal choices. For instance, it is well-documented that there is a gender gap in shopping behaviour (Klepek, 2020).

Although large-scale OECD studies (OECD, 2016, 2020) identified a gender gap in financial knowledge in most analysed countries, relatively few of them are characterised by a significant difference in the financial behaviour of women and men. The 2016 OECD report (OECD 2016, p. 45) concludes that the additional regression analyses "confirm that across the whole dataset, men and women did not score significantly differently on financial behaviour after controlling for country, age and education". In the 2020 edition of the report (OECD, 2020), a statistically significant gender gap in financial behaviour was found in only five out of twenty-five countries under study. One of them was Poland, where, interestingly, women reported better financial behaviour. OECD studies deserve special attention because they examine a wide range of financial behaviour (making considered purchases, keeping track of cash flow, saving, long-term planning, borrowing).

The null hypothesis assumed in this article $(\mathrm{H} 0)$ is that there is no gender gap in financial behaviour. Consequently, based on both the theoretical foundations regarding the relationship between gender and financial behaviour and the empirical findings gathered so far in prior research - as presented earlier in this section - we formulated the following alternative hypothesis:

H1: Financial behaviour of women differs significantly from men's financial behaviour with regard to all subdomains of financial management: cash management, savings and investment, credit management and insurance.

\section{Methods}

\subsection{Data and participants}

The data were collected in Poland from 500 heterosexual married or cohabitating couples (1,000 individuals) using an online questionnaire (CAWI - computer-assisted web interviewing) in December 2018. The survey was commissioned to a professional agency, DRB Research. The sample was controlled for cross-section quotas for age and region of residence. Table 1 presents the distribution of the sample in terms of standard sociodemographic characteristics. 


\begin{tabular}{|c|c|c|}
\hline Age (years, average) & 41.3 & 43.6 \\
\hline Education level & $\mathbf{N}$ & $\mathbf{N}$ \\
\hline Primary & 4 & 8 \\
\hline Lower secondary & 0 & 3 \\
\hline Basic vocational & 32 & 61 \\
\hline Secondary & 68 & 40 \\
\hline Secondary vocational & 79 & 123 \\
\hline Post-secondary school & 67 & 47 \\
\hline University-level & 236 & 198 \\
\hline At least PhD & 14 & 20 \\
\hline $\begin{array}{l}\text { Individual income (in } \\
\text { PLN, monthly) }\end{array}$ & $\mathbf{N}$ & $\mathbf{N}$ \\
\hline$<1500$ & 85 & 29 \\
\hline $1500-2500$ & 148 & 91 \\
\hline $2501-3500$ & 151 & 152 \\
\hline $3501-4500$ & 64 & 109 \\
\hline $4501-6000$ & 30 & 67 \\
\hline$>6000$ & 22 & 52 \\
\hline Marital status & $\mathbf{N}$ & $\mathbf{N}$ \\
\hline Married & 384 & 383 \\
\hline Cohabiting & 116 & 117 \\
\hline
\end{tabular}

EUR 1 = ca. PLN 4.5 in mid-January 2021, that is - when the article is accepted for publication.

Source: author

\subsection{Variables}

We decided to use the FMBS proposed by Dew and Xiao (2011) to measure our key variable - financial behaviour. The proposition assumes that there is a set of desirable (sound, healthy, prudent, responsible, positive) financial behaviours that consumers should undertake. For instance, keeping a financial record is desirable, while refraining from saving for retirement is undesirable. The scale was designed to probe the extent to which the surveyed individuals perform these behaviours based on their self-reports. The scale consists of 15 items (which describe the behaviours) and asks the respondents to indicate how often they have engaged in these activities in the past six months. The responses are given on a 5 -point Likert scale ranging from " $1=$ never" to " $5=$ always". As a result, the higher the FMBS score, the better financial behaviour. The scale was developed and validated to allow for reliable measurement of both the overall financial behaviour based on responses 
to all 15 items and the isolated behaviours in four distinct domains: cash management (4 items), savings and investment (5 items), credit management (3 items) and insurance (3 items). The FMBS was used in recent studies by Veiga et al. (2019) and, in a revised form, by Spuhler and Dew (2019), Lind et al. (2020) and Strömbäck et al. (2020).

We used three of the FMBS subscales (cash management, savings and investment, insurance) in their original form. However, we had to modify the credit management module. Two out of three items in the original credit management subscale refer to credit card usage. This is understandable, given that credit cards are commonly used in the United States, where the scale was designed, yet inadequate to the specificity of the Polish financial market. At the time our survey was conducted, only one in six adult Poles had a credit card (Polish Bank Association, 2017). For this reason, we had to replace the original credit management subscale with a novel instrument measuring consumers' behaviour in the credit domain. To do this, we applied the subscale developed and initially assessed by Cwynar (2020).

Just like all subscales included in the original FMBS, the modified credit management subscale - adjusted to the specificity of the credit market in Poland - asks the respondents the same question ("Indicate how often you have engaged in...") and uses a 5-point Likert scale. However, unlike the original subscale, it consists of five items. Consequently, the revised financial management behaviour scale used in this study consisted of 17 items; they can be seen in full in the Appendix to this article. Table 2 summarises the descriptive statistics for both the overall financial behaviour scale and the four distinguished subscales.

Table 2 | Financial behaviour variables - descriptive statistics

\begin{tabular}{lcccccccc}
\hline FMBS and its four subscales & N & Mean & Median & SD & Skewness & Kurtosis & Min & Max \\
\hline Cash management & 966 & 3.87 & 4.00 & 0.89 & -0.90 & 0.76 & 1 & 5 \\
Savings and investment & 926 & 3.43 & 3.60 & 1.11 & -0.49 & -0.53 & 1 & 5 \\
Insurance & 879 & 3.82 & 4.00 & 1.16 & -0.79 & -0.26 & 1 & 5 \\
Credit management & 727 & 2.69 & 2.60 & 1.25 & 0.21 & -1.14 & 1 & 5 \\
Overall financial behaviour & 980 & 3.49 & 3.47 & 0.86 & -0.18 & -0.36 & 1 & 5 \\
\hline
\end{tabular}

Notes: SD - standard deviation; Min - minimum value; Max - maximum value

Source: author

As in the original FMBS, the respondents could select "Not applicable" in response to any item. In the analyses, such responses were treated as missing data and were not included in the financial behaviour scores. For this reason, the number of valid responses $(\mathrm{N})$ in Table 2 differs among particular financial management subdomains: from 727 for credit management to 966 for cash management. These figures seem credible given that the share of Poles who have ever taken out a credit or a loan is about $75 \%$ (KRD Economic Information Bureau, 2018), while cash management is, for obvious reasons, a financial activity that is conducted by a large majority of consumers on a daily basis (Hilgert, Hogarth, \& Beverly, 2003). After removing the "Not applicable" responses, the missing financial behaviour scores were estimated based on the mean scores reported as responses to the remaining items within the respective sub-domains of financial management. 


\subsection{Analysis}

The analyses were divided into two stages. First, the credibility of all subscales and the overall FMBS was evaluated using Cronbach's alpha. Second, we used appropriate tests (ttest and Mann-Whitney $U$ test) to examine the statistical significance of differences in financial behaviour between female and male respondents. These comparisons were twofold. We compared women and men in the whole sample (1) ignoring the fact that they represent dyads (married or cohabitating couples) and (2) matching them into couples. In the latter case, gender differences were investigated within dyads (that is, using dependent subsamples), while in the former case, the subsamples were treated as independent. All analyses were conducted at the significance level of $\alpha=0.05$.

\section{Results}

The estimations of Cronbach's alpha gave satisfactory results, indicating that both the overall FMBS and the subscales are internally consistent and reliably measure the underlying constructs. Table 3 summarises the estimates of the alpha obtained in our study. For comparison, the estimates originally obtained by Dew and Xiao (2011) were as follows: 0.81 for the full FMBS, 0.63 for cash management, 0.78 for savings and investment, 0.73 for insurance and 0.57 for credit management.

Table 3 | Cronbach's alpha estimated for the overall FMBS and its four subscales

\begin{tabular}{lccc}
\hline FMBS and its four subscales & N & Number of items & Cronbach's alpha \\
\hline Cash management & 862 & 4 & 0.739 \\
Savings and investment & 696 & 5 & 0.861 \\
Insurance & 741 & 3 & 0.816 \\
Credit management & 573 & 5 & 0.891 \\
Overall financial behaviour & 477 & 17 & 0.884 \\
\hline
\end{tabular}

Source: author

We found no statistically significant differences between female and male respondents when comparing their financial behaviours using data from the independent subsamples (women and men not matched into couples). Table 4 summarises this part of the analyses.

Table 4 | T-test for significant differences between women and men in their financial behaviours based on data from the independent subsamples

\begin{tabular}{|c|c|c|c|c|c|c|c|c|c|}
\hline \multirow[t]{2}{*}{ FMBS and its four subscales } & \multicolumn{2}{|c|}{$\begin{array}{c}\text { Female } \\
(\mathrm{n}=488)\end{array}$} & \multicolumn{2}{|c|}{$\begin{array}{c}\text { Male } \\
(n=478)\end{array}$} & \multirow[b]{2}{*}{$t$} & \multirow[b]{2}{*}{$p$} & \multicolumn{2}{|c|}{$95 \% \mathrm{Cl}$} & \multirow[b]{2}{*}{ Cohen's $d$} \\
\hline & M & SD & $\mathbf{M}$ & SD & & & LL & UL & \\
\hline Cash management & 3.88 & 0.88 & 3.86 & 0.90 & 0.30 & 0.765 & -0.10 & 0.13 & 0.02 \\
\hline Savings and investment & 3.41 & 1.10 & 3.45 & 1.13 & -0.55 & 0.585 & -0.18 & 0.10 & 0.04 \\
\hline Insurance & 3.79 & 1.16 & 3.85 & 1.17 & -0.82 & 0.410 & -0.22 & 0.09 & 0.06 \\
\hline Credit management & 2.64 & 1.23 & 2.74 & 1.27 & -1.10 & 0.271 & -0.28 & 0.08 & 0.08 \\
\hline Overall financial management & 3.46 & 0.85 & 3.51 & 0.87 & -0.94 & 0.345 & -0.16 & 0.06 & 0.06 \\
\hline
\end{tabular}

Notes: M - mean; SD - standard deviation; $\mathrm{t}$ - t-test value; $\mathrm{p}$ - significance level; $\mathrm{Cl}$ - confidence interval; LL - lower limit; UL - upper limit

Source: author 
Nor did we find any significant gender differences in financial behaviours comparing female and male partners within couples. Table 5 shows our findings from the analysis of dependent subsamples of genders. Such findings mean that the null hypothesis must be accepted.

Table 5 | T-test for significant differences between women and men in their financial behaviours based on data from the dependent subsamples

\begin{tabular}{|c|c|c|c|c|c|c|c|c|c|}
\hline \multirow[t]{2}{*}{ FMBS and its four subscales } & \multicolumn{2}{|c|}{$\begin{array}{c}\text { Female } \\
(n=484)\end{array}$} & \multicolumn{2}{|c|}{$\begin{array}{c}\text { Male } \\
(n=484)\end{array}$} & \multirow[b]{2}{*}{$t$} & \multirow[b]{2}{*}{$p$} & \multicolumn{2}{|c|}{$95 \% \mathrm{Cl}$} & \multirow[b]{2}{*}{$\begin{array}{c}\text { Cohen's } \\
d\end{array}$} \\
\hline & $\mathbf{M}$ & SD & $\mathbf{M}$ & SD & & & LL & UL & \\
\hline Cash management & 3.88 & 0.87 & 3.87 & 0.90 & 0.26 & 0.797 & -0.08 & 0.10 & 0.01 \\
\hline Savings and investment & 3.42 & 1.08 & 3.46 & 1.12 & -0.84 & 0.403 & -0.14 & 0.06 & 0.04 \\
\hline Insurance & 3.78 & 1.15 & 3.86 & 1.15 & -1.48 & 0.140 & -0.18 & 0.03 & 0.07 \\
\hline Credit management & 2.67 & 1.20 & 2.76 & 1.25 & -1.69 & 0.091 & -0.20 & 0.02 & 0.09 \\
\hline Overall financial management & 3.46 & 0.85 & 3.51 & 0.87 & -1.48 & 0.139 & -0.12 & 0.02 & 0.07 \\
\hline
\end{tabular}

Notes: M - mean; SD - standard deviation; $\mathrm{t}$ - t-test value; $\mathrm{p}$ - significance level; $\mathrm{Cl}$ - confidence interval; LL - lower limit; UL - upper limit

Source: author

\section{Discussion}

We did not find evidence supporting the hypothesis that women behave differently from men when managing personal finances. This finding is in line with the results of OECD studies obtained in a sample of 30 countries (OECD, 2016). However, the finding is inconsistent with the results of many other studies suggesting a difference in the way women and men manage finances (see the literature review section of this article) as well as with the latest OECD report (OECD, 2020), in which Poland was among the five countries where significant differences in the financial behaviour of women and men were confirmed.

The theory of social identity predicts the occurrence of the gender gap in the financial domain - from knowledge, through attitudes, to behaviour, choices and outcomes. If financial management is socially considered to be a masculine domain, women will shy away from it in order to avoid the costs associated with violating social norms. There is a large body of evidence showing that women perform worse than men in financial literacy tests, which could indicate that the theoretical predictions are confirmed with respect to financial knowledge and skills. If this is the case, gender differences should also be visible in financial behaviour. The literature has long been documenting a positive association between financial literacy and prudent financial behaviour: more literate individuals are more likely to perform desirable financial behaviour (Stolper and Walter 2017 provide a comprehensive review of studies on this issue). Therefore, the absence of a gender gap in financial behaviour is puzzling.

However, there is an emerging strand of literature suggesting that gender differences in financial literacy scores may be attributable to measurement inaccuracy or may arise from distinct ways in which women and men respond to test questions. When accounted for different nature of incorrect and "Don't know" responses, financial literacy quizzes show a considerably smaller gender gap in test scores or the absence of a significant gender 
difference altogether (Bucher-Koenen, Alessie, Lusardi, \& van Rooij, 2016; Z. Chen \& Garand, 2018; Kim \& Mountain, 2019; Ooi, 2020). This may mean that, after all, women and men have comparable resources of financial knowledge and skills, while the only reason for worse results of female respondents in financial literacy tests is that women tend to admit if they do not know the correct answer, while men prefer to take a guess. ${ }^{1}$ This does not necessarily mean that the theory is not even confirmed with regard to financial literacy. Rather, this means that women have less confidence in their financial competences compared to men, presumably due to gender roles imposed by social norms - which is still consistent with the social identity theory. However, irrespective of differences in the domain-specific self-confidence, women still may have comparable resources of financial knowledge and skills. A similar mechanism may work with regard to financial behaviour. Emotionally, women may feel intimidated by financial matters, but when they deal with them, they do it just as well as men.

Assuming for a while that the gender gap in financial literacy does exist even though it is not detected in financial behaviour (as in our study), then there must be a mechanism closing the gap between financial literacy and financial behaviour. The conceptual model proposed and discussed by Huston (2010) indicates a wide range of factors that can influence financial behaviour above and beyond the impact of financial literacy - from economic conditions, through time preferences, to behavioural biases. There is a lot of room for future research exploring this set of factors as possible explanations for the absence of a gender gap in financial behaviour.

One cannot also rule out the possibility that the results that we obtained are countryspecific. Several studies observed that the gender gap in financial literacy and attitudes is less common in Eastern Europe compared to more developed Western European countries (Białowolski, Cwynar, Cwynar, \& Węziak-Białowolska, 2020; Bucher-Koenen et al., 2017; Cupák et al., 2018; Cwynar, Cwynar, Dankiewicz, Ostrowska-Dankiewicz, \& Oratowski, 2019; Klapper \& Panos, 2011). This increases the likelihood of insignificant gender differences in financial behaviour in Eastern Europe, including Poland. Again, the social identity theory is useful in explaining the specificity of Eastern Europe in this regard. Although today Poland is one of the European countries with a low value of the Gender Equality Index (55.8 versus 67.9 for the European Union) (European Institute for Gender Equality, 2020), the difficult living conditions behind the Iron Curtain for almost fifty years may have caused that the distinction between archetypal masculine and feminine tasks got blurred in Eastern European states, including Poland. Living in a country suffering from constant shortages of goods required a lot of ingenuity and resourcefulness from both genders - not only men. Perhaps keeping up with men in this respect made it easier for women to acquire and absorb financial knowledge and good habits later, i.e. when their countries underwent a systemic transformation towards democracy and capitalism and, possibly, more egalitarian societies (Bucher-Koenen et al., 2017).

Finally, a large part of the literature devoted to how women and men differ in their financial competences focuses on the outcomes of financial behaviours rather than on evaluating the behaviours themselves (Dew \& Xiao, 2011). One cannot rule out the possibility that despite the absence of significant gender differences in financial behaviours, due to other factors,

${ }^{1}$ A greater inclination to select the "Don't know" response can also mask higher risk aversion of women (Z. Chen \& Garand, 2018; Lizotte \& Sidman, 2009). 
women and men differ in the outcomes of these behaviours - for instance, in the accumulated wealth or assumed debt.

\section{Conclusions, implications, limitations and future research}

The literature on financial literacy considers women a disadvantaged social group that requires special care aimed at improving their preparedness to participate in financial markets. However, the study discussed in this article showed that women do not necessarily behave worse financially. Given that it is highly plausible that the patterns of their financial behaviour arise from pressures exerted by social norms, programmes designed with the financial competence of women in mind should emphasise emotional (and more broadly - psychological) and social circumstances and conditions of their finance-related actions rather than focus on the need to provide them with additional knowledge or to train their skills and change their habits. Given the business context, the findings presented in this article may shed additional light on the controversies around women's predispositions to manage finances and, more broadly, their managerial predispositions in general. Although the study demonstrated in this article is microeconomic and, as such, it cannot be conclusive on the managerial grounds, it showed that women are not less financially savvy in terms of financial behaviour. As a result, it seems that future management studies should at least begin any exploration of gender differences in business activity with the general hypothesis that women are not less predisposed to effectively participate in economic enterprises and, possibly, in the management of organisations.

As usual, there are some limitations to the present study that, at the same time, suggest directions for future research. Such directions have been outlined in the discussion section above. The aim of the study was to explore the differences between women and men in terms of financial behaviour. Hence, the appropriate statistical tests of significant differences were used. However, such tests do not allow for examining the causes of the differences found or the causes of their absence. Therefore, the application of other methods (e.g. regression models) is recommended.

In this study, the respondents' financial behaviour was measured through self-reports. For this reason, the obtained levels of financial behaviour might have been subject to the social desirability effect. It is recommended that these findings should be verified in future research using other measures of financial behaviour.

Finally, our sample does not allow for generalisation of results to the whole population of adult Poles. This would require asking the same questions in a nationally representative sample.

\section{Acknowledgement}

This work was supported by Polish Ministry of Science and Higher Education grant [contract no. 0057/DLG/2016/10 under the program 'Dialogue' (within project entitled 'Debt Watch')]. 


\section{References}

Adams, R. B., \& Ragunathan, V. (2017). Lehman Sisters. SSRN Electronic Journal. https://doi.org/10.2139/ssrn.3046451

Agarwal, S., He, J., Sing, T. F., \& Zhang, J. (2018). Gender gap in personal bankruptcy risks: Empirical evidence from Singapore. Review of Finance, 22(2), 813-847. https://doi.org/10.1093/rof/rfw063

Agnew, J., Balduzzi, P., \& Sundén, A. (2003). Portfolio choice and trading in a large 401 (k) plan. American Economic Review, 93(1), 193-215. https://doi.org/10.1257/000282803321455223

Agnew, S., Maras, P., \& Moon, A. (2018). Gender differences in financial socialisation in the home-An exploratory study. International Journal of Consumer Studies, 42(3), 275-282. https://doi.org/10.1111/ijcs. 12415

Akerlof, G. A., \& Kranton, R. E. (2000). Economics and identity. Quarterly Journal of Economics, 115(3), 715-753. https://doi.org/10.1162/003355300554881

Almenberg, J., \& Dreber, A. (2015). Gender, stock market participation and financial literacy. Economics Letters, 137, 140-142. https://doi.org/10.1016/j.econlet.2015.10.009

Atkinson, S. M., Baird, S. B., \& Frye, M. B. (2003). Do female mutual fund managers manage differently? Journal of Financial Research, 26(1), 1-18. https://doi.org/10.1111/1475-6803.00041

Babiarz, P., Robb, C. A., \& Woodyard, A. (2012). Family Decision Making and Resource Protection Adequacy. Journal of Consumer Affairs, 46(1), 1-36. https://doi.org/10.1111/j.17456606.2012.01224.x

Baeckstrom, Y., Marsh, I. W., \& Silvester, J. (2019). Financial Advice, Wealth and Gender: Risk Tolerance, Knowledge and Confidence. SSRN Electronic Journal. https://doi.org/10.2139/ssrn.3286336

Bajtelsmit, V. L., Bernasek, A., \& Jianakoplos, N. A. (1999). Gender differences in defined contribution pension decisions. Financial Services Review, 8(1), 1-10. https://doi.org/10.1016/s10570810(99)00030-x

Barasinska, N., \& Schäfer, D. (2018). Gender role asymmetry and stock market participation-evidence from four European household surveys. European Journal of Finance, 24(12), 1026-1046. https://doi.org/10.1080/1351847X.2017.1371622

Barber, B. M., \& Odean, T. (2001). Boys will be boys: Gender, overconfidence, and common stock investment. Quarterly Journal of Economics, 116(1), 261-292. https://doi.org/10.1162/003355301556400

Beckmann, D., \& Menkhoff, L. (2008). Will women be women? Analysing the gender difference among financial experts. Kyklos. International Review for Social Sciences, 61(3), 364-384. https://doi.org/10.1111/j.1467-6435.2008.00406.x

Berger, A. N., Kick, T., \& Schaeck, K. (2014). Executive board composition and bank risk taking. Journal of Corporate Finance, 28(C), 48-65. https://doi.org/10.1016/j.jcorpfin.2013.11.006

Bernasek, A., \& Bajtelsmit, V. L. (2002). Predictors Of Women's Involvement In Household Financial Decision-Making. Financial Counseling and Planning, 13(2), 39-47.

Białowolski, P., Cwynar, A., Cwynar, W., \& Węziak-Białowolska, D. (2020). Consumer debt attitudes: The role of gender, debt knowledge and skills. International Journal of Consumer Studies, 44(3), 191-205. https://doi.org/10.1111/ijcs. 12558

Białowolski, P., Cwynar, A., \& Węziak-Białowolska, D. (2020). Financial management, division of 
financial management power and financial literacy in the family context - evidence from relationship partner dyads. International Journal of Bank Marketing, 38(6), 1373-1398. https://doi.org/10.1108/IJBM-01-2020-0023

Black, S. E., Devereux, P. J., Lundborg, P., \& Majlesi, K. (2017). On the Origins of Risk-Taking in Financial Markets. Journal of Finance, 72(5), 2229-2278. https://doi.org/10.1111/jofi.12521

Boggio, C., Fornero, E., Prast, H., \& Sanders, J. (2015). Seven Ways to Knit Your Portfolio. Is Investor Communication Neutral? (No. DP 10/2015-030).

Booth, A. L., \& Nolen, P. (2012). Gender differences in risk behaviour: Does nurture matter? Economic Journal, 122(558), F56-F78. https://doi.org/10.1111/j.1468-0297.2011.02480.x

Brown, M., \& Graf, R. (2013). Financial Literacy and Retirement Planning in Switzerland. Numeracy, 6(2), Article 6. https://doi.org/10.5038/1936-4660.6.2.6

Bucher-Koenen, T., Alessie, R., Lusardi, A., \& van Rooij, M. (2016). Women, Confidence, and Financial Literacy. Luxembourg.

Bucher-Koenen, T., Lusardi, A., Alessie, R., \& van Rooij, M. (2017). How Financially Literate Are Women? An Overview and New Insights. Journal of Consumer Affairs, 51(2), 255-283. https://doi.org/10.1111/joca.12121

Byrnes, J. P., Miller, D. C., \& Schafer, W. D. (1999). Gender differences in risk taking: A meta-analysis. Psychological Bulletin, 125(3), 367-383. https://doi.org/10.1037/0033-2909.125.3.367

Calcagnini, G., Giombini, G., \& Lenti, E. (2015). Gender Differences in Bank Loan Access: An Empirical Analysis. Italian Economic Journal, 1(2), 193-217. https://doi.org/10.1007/s40797014-0004-1

Caliendo, M., Fossen, F. M., Kritikos, A., \& Wetter, M. (2015). The gender gap in entrepreneurship: Not just a matter of personality. CESifo Economic Studies, 61(1), 202-238. https://doi.org/10.1093/cesifo/ifu023

Catsalyst. (2020). Pyramid: Women in S\&P 500 Companies. Retrieved from https://www.catalyst.org/research/women-in-sp-500-companies/

Charness, G., \& Gneezy, U. (2012). Strong Evidence for Gender Differences in Risk Taking. Journal of Economic Behavior and Organization, 83(1), 50-58. https://doi.org/10.1016/j.jebo.2011.06.007

Chen, X., Huang, B., \& Ye, D. (2019). The Gender Gap in Peer-to-Peer Lending: Evidence from the People's Republic of China (No. 977). https://doi.org/10.2139/ssrn.3541481

Chen, Z., \& Garand, J. C. (2018). On the Gender Gap in Financial Knowledge: Decomposing the Effects of Don't Know and Incorrect Responses. Social Science Quarterly, 99(5), 1551-1571. https://doi.org/10.1111/ssqu. 12520

Cupák, A., Fessler, P., Schneebaum, A., \& Silgoner, M. (2018). Decomposing gender gaps in financial literacy: New international evidence. Economics Letters, 168(C), 102-106. https://doi.org/10.1016/j.econlet.2018.04.004

Cwynar, A. (2020). Financial Literacy, Behaviour and Well Being of Millennials in Poland Compared to Previous Generations: The Insights from Three Large Scale Surveys. Review of Economic Perspectives, 20(3), 289-335. https://doi.org/10.2478/revecp-2020-0015

Cwynar, A., Cwynar, W., Dankiewicz, R., Ostrowska-Dankiewicz, A., \& Oratowski, P. (2019). Why do consumers remain financially illiterate? The empirical test of some less investigated reasons. Journal of Eastern European and Central Asian Research, 6(1), 40-55. https://doi.org/10.15549/jeecar.v6i1.285 
de Andrés, P., Gimeno, R., \& de Cabo, R. M. (2019). The gender gap in bank credit access (No. 1945). Retrieved

https://www.bde.es/f/webbde/SES/Secciones/Publicaciones/PublicacionesSeriadas/Documentos Trabajo/19/Fich/dt1945e.pdf

Dew, J., \& Xiao, J. J. (2011). The Financial Management Behavior Scale: Development and Validation. Journal of Financial Counseling and Planning, 22(1), 43-59.

Dohmen, T., Falk, A., Huffman, D., Sunde, U., Schupp, J., \& Wagner, G. G. (2011). Individual risk attitudes: Measurement, determinants, and behavioral consequences. Journal of the European Economic Association, 9(3), 522-550. https://doi.org/10.1111/j.1542-4774.2011.01015.x

Driva, A., Lührmann, M., \& Winter, J. (2016). Gender differences and stereotypes in financial literacy: Off to an early start. Economics Letters, 146(C), 143-146. https://doi.org/10.1016/j.econlet.2016.07.029

European Institute for Gender Equality. (2020). Gender Equality Index 2020 Digitalisation and the future of work. Retrieved from file:///C:/Users/Andrzej/Downloads/mhaf20001enn_002.pdf

Filipiak, U., \& Walle, Y. M. (2015). The Financial Literacy Gender Gap: A Question of Nature or Nurture? Courant Research Centre: Poverty.

Fisher, P. J. (2010). Gender differences in personal saving behaviors. Journal of Financial Counseling and Planning, 21(1), 14-24.

Fisher, P. J., Hayhoe, C., \& Lown, J. (2015). Gender Differences in Saving Behaviors among Low- to Moderate-Income Households. Financial Services Review, 24(1), 1-13.

Getmansky Sherman, M., \& Tookes, H. (2020). Female Representation in the Academic Finance Profession. SSRN Electronic Journal. https://doi.org/10.2139/ssrn.3438653

Gneezy, U., Leonard, K. L., \& List, J. A. (2009). Gender Differences in Competition: Evidence From a Matrilineal and a Patriarchal Society. Econometrica, 77(5), 1637-1664. https://doi.org/10.3982/ecta6690

Guzman, J., \& Kacperczyk, A. (Olenka). (2019). Gender gap in entrepreneurship. Research Policy, 48(7), 1666-1680. https://doi.org/10.1016/j.respol.2019.03.012

Hasler, A., \& Lusardi, A. (2017). The Gender Gap in Financial Literacy: A Global Perspective. In Global Financial Literacy Excellence Center. Washington, DC.

Hilgert, M. A., Hogarth, J. M., \& Beverly, S. G. (2003). Household Financial Management: The Connection between Knowledge and Behavior. Federal Reserve Bulletin, July, 309-322.

Hsu, J. W. (2016). Aging and Strategic Learning: The Impact of Spousal Incentives on Financial Literacy. Journal of Human Resources, 51(4), 1036-1067. https://doi.org/10.3368/jhr.51.4.1014$6712 \mathrm{R}$

Huang, J., \& De Luca, T. J. (2020). The same but different: Gender and investor behavior in Vanguard retail accounts. Malvern, PA.

Hung, A., Yoong, J., \& Brown, E. (2012). Empowering Women Through Financial Awareness and Education. In OECD Working Papers on Finance, Insurance and Private Pensions, No. 14. https://doi.org/10.1787/5k9d5v6kh56g-en

Huston, S. J. (2010). Measuring Financial Literacy. Journal of Consumer Affairs, 44(2), 296-316. https://doi.org/10.1111/j.1745-6606.2010.01170.x

Johar, M., \& Rammohan, A. (2011). The Role of Family Networks and Gender on Borrowing Behavior in Indonesia. The Journal of Developing Areas, 45(1), 111-134. 
Johnson, J. E. V., \& Powell, P. L. (1994). Decision Making, Risk and Gender: Are Managers Different? British Journal of Management, 5(2), 123-138. https://doi.org/10.1111/j.14678551.1994.tb00073.x

Kanze, D., Huang, L., Conley, M. A., \& Tory Higgins, E. (2018). We ask men to win and women not to lose: Closing the gender gap in startup funding. Academy of Management Journal, 6(2), 586614. https://doi.org/10.5465/amj.2016.1215

Ke, D. (2018). Cross-Country Differences in Household Stock Market Participation: The Role of Gender Norms. AEA Papers and Proceedings, 108, 159-162. https://doi.org/10.1257/pandp.20181097

Kim, N., \& Mountain, T. P. (2019). Financial knowledge and "Don't Know" Response. Journal of Consumer Affairs, 53(4), 1948-1969. https://doi.org/10.1111/joca.12275

Klapper, L., \& Panos, G. A. (2011). Financial literacy and retirement planning: the Russian case. Journal of Pension Economics \& Finance, 10(4), 599-618. https://doi.org/10.1017/S1474747211000503

Klepek, M. (2020). The role of demographic factors in consumer perception of value from brand communication on facebook. Central European Business Review, 9(3), 56-73. https://doi.org/10.18267/j.cebr.239

KRD Economic Information Bureau. (2018). Dlaczego Polacy się zadłużają. Wrocław.

Lind, T., Ahmed, A., Skagerlund, K., Strömbäck, C., Västfjäll, D., \& Tinghög, G. (2020). Competence, Confidence, and Gender: The Role of Objective and Subjective Financial Knowledge in Household Finance. Journal of Family and Economic Issues, Early View. https://doi.org/10.1007/s10834-020-09678-9

Lindquist, G. S., \& Säve-Söderbergh, J. (2011). "Girls will be Girls", especially among Boys: Risk-taking in the "Daily Double" on Jeopardy. Economics Letters, 112(2), 158-160. https://doi.org/10.1016/j.econlet.2011.04.010

Lizotte, M. K., \& Sidman, A. H. (2009). Explaining the Gender Gap in Political Knowledge. Politics and Gender, 5(2), 127-151. https://doi.org/10.1017/S1743923X09000130

Lusardi, A., \& Mitchell, O. S. (2008). Planning and financial literacy: How do women fare? American Economic Review, 98(2), 413-417. https://doi.org/10.1257/aer.98.2.413

Markussen, S., \& Røed, K. (2017). The gender gap in entrepreneurship - The role of peer effects. Journal of Economic Behavior and Organization, 134(C), 356-373. https://doi.org/10.1016/j.jebo.2016.12.013

Mattia, L., Huston, S. J., \& Finke, M. S. (2017). Marriage and the Financial Knowledge Gender Gap. SSRN Electronic Journal. https://doi.org/https://dx.doi.org/10.2139/ssrn.3282035

Meyll, T., \& Pauls, T. (2019). The gender gap in over-indebtedness. Finance Research Letters, 31(C). https://doi.org/10.1016/j.frl.2018.12.007

Moon, C. S., Ohk, K., \& Choi, C. (2014). Gender differences in financial literacy among Chinese university students and the influential factors. Asian Women, 30(2), 3-25. https://doi.org/10.14431/aw.2014.03.30.2.3

Nitani, M., Riding, A., \& Orser, B. (2020). Self-employment, gender, financial knowledge, and high-cost borrowing. Journal of Small Business Management, 58(4), 669-706. https://doi.org/10.1080/00472778.2019.1659685

OECD. (2016). International survey of adult financial literacy competencies. Paris. 
OECD. (2020). OECD/INFE 2020 International Survey of Adult Financial Literacy. Paris.

Ooi, E. (2020). Give mind to the gap: Measuring gender differences in financial knowledge. Journal of Consumer Affairs, 54(3), 931-950. https://doi.org/10.1111/joca.12310

Polish Bank Association. (2017). Raport ZBP Info Kredyt. Warsaw.

Powell, M., \& Ansic, D. (1997). Gender differences in risk behaviour in financial decision-making: An experimental analysis. Journal of Economic Psychology, 18(6), 605-628. https://doi.org/10.1016/S0167-4870(97)00026-3

Preston, A. C., \& Wright, R. E. (2019). Understanding the Gender Gap in Financial Literacy: Evidence from Australia. Economic Record, 95(S1), 1-29. https://doi.org/10.1111/1475-4932.12472

Säve-Söderbergh, J. (2012). Self-Directed Pensions: Gender, Risk, and Portfolio Choices. Scandinavian Journal of Economics, 114(3), 705-728. https://doi.org/10.1111/j.14679442.2012.01710.x

Schubert, R., Brown, M., Gysler, M., \& Brachinger, H. W. (1999). Financial decision-making: Are women really more risk-averse? American Economic Review, 89(2), 381-385. https://doi.org/10.1257/aer.89.2.381

Smith, J. P., McArdle, J. J., \& Willis, R. (2010). Financial Decision Making and Cognition in a Family Context. The Economic Journal, 120(548), F363-F380. https://doi.org/10.1111/j.14680297.2010.02394.x

Spuhler, B. K., \& Dew, J. (2019). Sound Financial Management and Happiness: Economic Pressure and Relationship Satisfaction as Mediators. Journal of Financial Counseling and Planning, 30(2), 157-174. https://doi.org/10.1891/1052-3073.30.2.157

Stolper, O. A., \& Walter, A. (2017). Financial literacy, financial advice, and financial behavior. Journal of Business Economics, 87(5), 581-643. https://doi.org/10.1007/s11573-017-0853-9

Strömbäck, C., Skagerlund, K., Västfjäll, D., \& Tinghög, G. (2020). Subjective self-control but not objective measures of executive functions predicts financial behavior and well-being. Journal of Behavioral and Experimental Finance, 27, Early View. https://doi.org/10.1016/j.jbef.2020.100339

Tajfel, H., \& Turner, J. (1979). An integrative theory of intergroup conflict. In W. G. Austin \& S. Worchel (Eds.), The social psychology of intergroup relations (pp. 33-57). Monterey, CA: Wadsworth.

van Rooij, M., Lusardi, A., \& Alessie, R. (2011). Financial literacy and stock market participation. Journal of Financial Economics, 101(2), 449-472. https://doi.org/10.1016/j.jfineco.2011.03.006

van Staveren, I. (2001). Gender biases in finance. Gender and Development, 9(1), 9-17. https://doi.org/10.1080/13552070127734

Veiga, R. T., Avelar, C., Moura, L. R. C., \& Higuchi, A. K. (2019). Validation of scales to research the personal financial management. Revista Brasileira de Gestao de Negocios, 21(2), 332-348. https://doi.org/10.7819/rbgn.v21i2.3976

Ward, A., \& Lynch, J. (2019). On a need-to-know basis: How the distribution of responsibility between couples shapes financial literacy and financial outcomes. Journal of Consumer Research, 45(5), 1013-1036. https://doi.org/doi.org/10.1093/jcr/ucy037

Weber, M., Weber, E. U., \& Nosić, A. (2013). Who takes risks when and why: Determinants of changes in investor risk taking. Review of Finance, 17(3), 847-883. https://doi.org/10.1093/rof/rfs024 


\section{Appendix}

Financial management behaviour scale based on Dew and Xiao (2011)

On a scale of 1 to 5 (where 1 means never, 2 - seldom, 3 - sometimes, 4 - often, 5 always), please indicate how often you have engaged in the following activities in the past six months. You can also say "Not Applicable (N/A)"

Cash management

a) Comparison shopped when purchasing a product or service.

b) Paid all your bills on time.

c) Kept a written or electronic record of your monthly expenses.

d) Stayed within your budget or spending plan.

Savings and investment

a) Began or maintained an emergency savings fund.

b) Saved money from every paycheck.

c) Saved for a long term goal such as a car, education, home, etc.

d) Contributed money to a retirement account.

e) Bought bonds, stocks, or mutual funds.

Insurance

a) Maintained or purchased an adequate health insurance policy (e.g. in the case of serious diseases).

b) Maintained or purchased adequate property insurance like auto or homeowners insurance.

c) Maintained or purchased adequate life insurance.

Credit management (revised subscale)

a) Made only minimum payments on a loan.

b) Borrowed to pay off a debt.

c) Got behind on debt repayment, including interest on debt.

d) Borrowed simultaneously from more than one source (e.g. banks, personal loan/payday loan companies, instalment purchases, pawnshops, family, etc.).

e) Borrowed for at least one of the following purposes (or for similar purposes): the purchase of expensive clothing or accessories, a holiday abroad, technological novelties or gadgets.

The research paper passed the review process. | Received: November 19, 2020; Revised: December 19, 2020; Accepted: January 19, 2021; Pre-published online: February 27, 2021;

Published in the regular issue: December 6, 2021. 